„Bohemistyka” 2021, nr 4, ISSN 1642-9893

Kateřina SACHROVÁ

DOI: $10.14746 /$ bo.2021.4.7

Charles University

\section{Authentic Literature in Textbooks of Czech as a Foreign Language}

Keywords: literary style, literary texts, Czech language, authentic materials, textbooks

\section{Abstract}

Usage of the literary style is an important part of teaching and learning Czech as a native or foreign language. The literary style, or more exactly, the style of literature, drama and poetry, is an important way of that representing the culture at the basis of the taught language. In this paper, we provide a short outline of the problem of authenticity in textbooks of Czech as a foreign language. The aim of this article is to present some of the aspects of using authentic literary texts in modern communicative textbooks. The study is based on analysis of the textual content of contemporary teaching materials.

\section{Introduction}

What role does the authenticity of texts play in language education? Why are literary texts suitable for the content of textbooks? Do authors of teaching materials really use authentic texts to create textbooks? What is the attitude of teachers of Czech as a Foreign Language to this issue? The aim of this article is to think about these questions and to suggest some answers. The general consideration of these issues and the theoretical background are supported by particular results of a textual analysis of textbooks for students of Czech as a Foreign Language.

\section{The issue of textual authenticity in foreign language education}

The authenticity of teaching materials in language education is one of the topics that have been discussed at a number of language confer- ences. Didacticians and foreign language teachers are very interested and involved in this subject. Foreign language education that is in accordance with the communicative method uses authentic texts, i.e. texts which are not primarily intended for the needs of language teaching and learning. Their indisputable advantage, and a key quality at the same time, is their connection to real life. Authentic texts can also be an important motivational tool if they are appropriately and purposefully chosen. Another advantage is that linguistic structures are naturally presented in these texts and the choice of words is based on the needs of a particular communication situation. Last but not least is the importance of the easy accessibility of such materials.

Work with authentic materials is regarded with caution by many teachers, especially when we talk about teaching beginners. These teachers usually object that authentic materials are too complicated and time-consuming, they cannot replace the textbook, and they are not very useful for teaching grammar. In general, they reccomend artificially created texts for beginners, and adapted or authentic texts for students with a higher level of knowledge (Škodová, 2012). Choděra, who sees the text as a core of all foreign language teaching and learning, puts the question of the originality (authenticity) of a text against its adequacy. As a compromise he suggests using adapted texts (Choděra \& Ries, 1999, pp. 86-87). We assume that both teachers looking for appropriate texts for their lessons and authors engaged in the process of the creation of textbooks should be able to choose suitable materials with respect to the level and maturity of students. Thanks to their skills and experience, teachers and authors should $m e$ diate the authentic texts without having to simplify them:

Each authentic text is based on a particular situation, and the language level of these materials is variable. Therefore, it is possible to find and then use both simple texts (corresponding to levels A1 and A2) and quite complicated texts that correspond to higher language levels (Roubalová, 2006, p. 194).

Even working with a textbook can be time-consuming. However, it depends on the teacher how effectively he/she uses the time designated to lesson preparation. The aim of working with authentic materi- 
als is not to replace the textbook but to complement it, and to help students achieve the required level of language knowledge according to CEFR. Certain grammatical structures are contained in every authentic text. The teacher should be able to find a suitable text and to use it for practice or presentation of grammar.

As we have already mentioned, the adapted text can become a good compromise between an original text (in some cases more difficult from the point of view of comprehension) and an artificially created text. However, Desbois (2009) admits that the inadequacy of a text in relation to the achieved language level of a student does not have to be an obstacle: "If we offer a text without its modification (i.e. simplifying or shortening it in order to summarize its parts), we expect a certain imbalance at the level of difficulty that can motivate students during their reading" (Desbois, 2009, p. 10).

Desbois gives an example of a short poem of Jacques Prévert which can be used to practise French relative pronouns. These poems are written in very simple language; therefore they are suitable for beginners. Working with unadapted texts is recommended by Lenčová. In relation to the use of an original literary text, she points out the fact that "interference into the form and content of a piece of art can cause its devaluation" (Lenčová, 2005, p. 44). The unmodificated poetic text is also seen as an appropriate authentic material by Cudak (2004, pp. 101-110)

Work with authentic textual materials is considered stimulating and motivating for both students and teachers. If a teaching material contains such a text, it is indisputably an advantage for the person who prepares a language lesson. As the society changes, the character of some texts (official forms, standard letters, etc.) also changes. Updating these texts can be a problem if they are integrated into textbooks that become outdated. On the contrary, when we talk about authentic literary texts, they remain constant and unchangeable, which can be seen as their advantage.

When choosing a suitable authentic text for classes or creating other learning material, we should pay attention to such issues as motivation, age and maturity, continuity in learning activities, target achievement and the issue of acceptability (respecting cultural, religious and other customs of students).

\section{Authentic literary texts in textbooks of Czech for Foreigners}

We believe that text examples from poetry, fiction and drama in their unmodificated form are appropriate authentic materials that can be used for teaching all communication skills and language knowledge. In the following part of this article, we are going to briefly introduce a research study that was done by the author, and that deals with the issue in question in detail. Given the extensiveness of the research and the main topic of this article, we are focusing only on the results relating to authentic literary texts.

The Literary Style in Teaching and Learning Czech as a Foreign Language (Sachrová 2019) was the subject of quantitative research. Its main part focused on the textual analysis of textbooks of Czech as a Foreign Language for adult learners. The aim of the research was to determine the percentage of the representation of literary texts in chosen textbooks.

The research sample consisted of 49 publications that were available on the Czech market and actively used by teachers of Czech as a Foreign Language as a primary or complementary teaching material. The total number of analyzed books included also individual parts of textbook sets. The results of the analysis were classified according to the levels of knowledge according to CEFR, so that it would cover the functional-stylistic characteristics of texts in textbooks for all levels taught, i.e. A1-C1. Level C2 was omitted because none of the researched books expected achievement of this level. Furthermore, this level has not been described yet for Czech as a Foreign Language.

Firstly, graphing was used to show the percentage of representation of particular types of literary style. The most frequently represented literary genres and subgenres were then shown in graphs: the aim was to find out which type of texts are most often used by textbook authors to give examples of the literary style. Next, the percentage of authentic and adapted texts was also shown in graphs (see be- 
low in more detail). Additionally, the author focused on the types of tasks relating to particular extracts. Finally, it was noted which Czech authors have been frequently or rarely mentioned in textbooks. All these findings were evaluated. The final, additional part was based on results of a questionnaire distributed among teachers of Czech as a Foreign Language.

\subsection{Results of analysis and questionnaire}

Authentic texts are the most represented ones in the analyzed textbooks $(68 \%)$. The reason why authentic texts predominate is, among other things, the fact that short authentic texts, such as proverbs, sayings, rhymes and songs in textbooks do not need to be adapted to lower language level.

Re d u c ed te $\mathrm{xts}$ are also included among adapted texts (14\%) if it is mentionned by the textbook author that the text was reduced. The third group consists of the a rt ific i a l te $\mathrm{xts}$ created by textbook authors (or other didacticians) just for educational needs. Their number $(14 \%)$ roughly corresponds to the number of adapted and reduced texts. The fourth group consists of those texts where it is impossible to determine whether the texts are authentic or not. The reason for this is the missing information about the source of these texts, including the name of the author. For results of this analysis, see Figure 1.

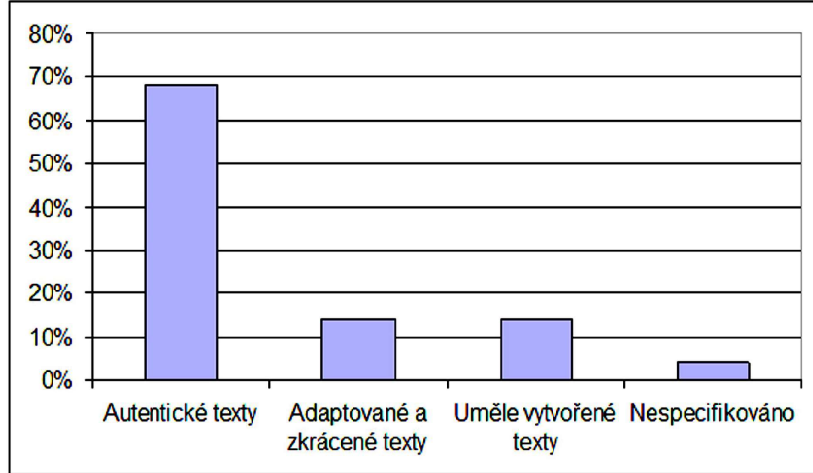

Figure 1. Representation of authentic, adapted and artificially created texts
The content analysis of textbooks was complemented by the exploratory method of questioning to acquire the most complex reasearch results possible. In this part of the research, the author was trying to find out what the experience, needs and attitude of teachers are in relation to the use of the literary style in lessons of Czech as a Foreign Language.

The aim of the questionnaire was to inquire if and how the teachers work with the literary style and, from this point of view, how they evaluate the teaching material used. The questionnaire was anonymous. Respondents were teachers of Czech as a Foreign Language and methodology specialists who are engaged in teaching only those foreigners who do not study Czech as a main subject. The questionnaire did not distinguish which students' age group or type of language course it should apply to; the questionnaire was completed by both university teachers and teachers from other institutions (private or public).

48 respondents $(87 \%)$ out of 55 (total number) replied that they had used literary texts in lessons of Czech as a Foreign Language. 21 respondents prefer working with authentic texts, 12 respondents prefer adapted texts, and 15 respondents work with both authentic and adapted texts. Respondents from the last group stated that the language level of students' knowledge had decided whether the authentic or adapted texts would have been chosen. According to the teachers, adapted texts are more suitable for lower knowledge levels, and authentic texts for more advanced students. For results of this part of the questionnaire, see Figure 2.

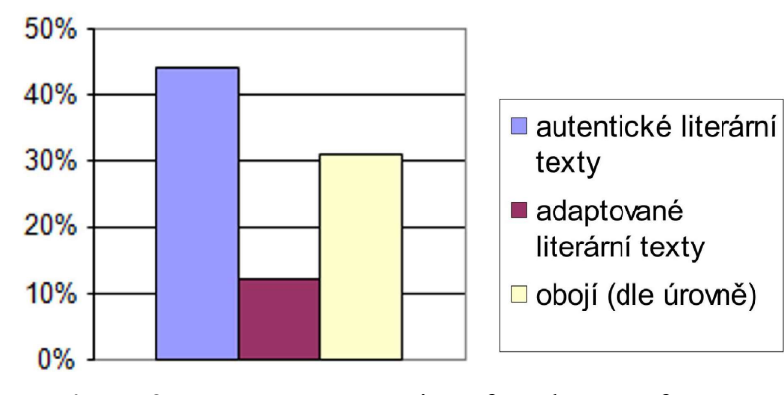

Figure 2. Percentage expression of teachers' preferences 


\subsection{Evaluation of research results}

Based on the text analysis and the questionnaire, it can be affirmed that both teachers and authors of teaching materials prefer authentic texts. At the same time, we cannot omit the adapted and artificially created texts that are particularly used in teaching students with a lower level of language knowledge. However, the aim of the research was to show that authentic literary texts could be used across all language levels of CEFR.

Using the text analysis, the researcher tried to find out how much the authors include authentic and adapted texts in their textbooks. It was not possible to come to clear conclusions because of the fact that some authors did not mention the source of the chosen literary extract. It was therefore difficult to identify whether the text was authentic, adapted to a particular knowledge level, or even artificially created for the textbook user's needs. This fact is considered the textbook author's failure not only from the point of view of quotation rules, but also from the user's point of view. If students encounter a literary extract in a textbook, they also need to know the writer's name and the work's title, or the fact that they are dealing with folklore literature. The students should be given the chance to follow up this author in order to read the whole book, for example, if they are interested in Czech culture and literature. The missing information also complicates assigning the extract to a particular literature genre and subgenre.

\section{Conclusion}

The work with teaching materials is a key part in the process of education, and their choice is one of the most important tasks of each teacher of Czech as a Foreign Language. Authenticity as a connection of the educational content to reality should not disappear from Czech lessons. We have introduced the original literary text as an example of an important type of authentic content that helps students achieve several learning targets. Poetry, fiction and drama are valuable sources of cultural knowledge, which is more than desirable in lessons of Czech language. That is the reason why original literature should not be forgotten. Apart from representing the culture, all texts of the literary style can be used for grammar and vocabulary practice. They can help students understand syntactic structures, pronunciation rules, and Czech phonetics. It follows that including authentic literary examples in textbooks is important for effective work in classes of Czech as a Foreign Language across all levels of language knowledge.

\section{References}

$\mathrm{C}$ u d a k R., 2004, The Poetic Text in Teaching a Foreign Language, Canadian Slavonic Papers / Revue Canadienne des Slavistes, Vol. 46, No. 1/2, pp. 101$-110$

D e s b o is A., 2009, Pour une didactique de la stylistique en classe de français langue étrangčre, Grenoble: Université Stendhal-Grenoble III.

H e n dri c h J. a kol.,1988, Didaktika cizích jazyki̊, Praha: Státní pedagogické nakladatelství.

Chod ěra R., Ri es L.,1999, Výuka cizích jazyků na prahu nového století, Ostrava: Ostravská univerzita.

L e nč o vá I., 2005, Literárny text v cudzojazyčnej edukácii, Banská Bystrica: Univerzita Mateja Bela.

P e y t a r d J., 1982, Littérature et classe de langue, Paris: Crédif - Hatier.

R o u b a lo vá E., 2006, Výuka reálií - neodmyslitelná součást cizojazyčné výuky, Bohemistyka, No. 3, pp. 193-198.

S a c h r o vá K., 2019, Umělecký styl ve výuce češtiny pro jinojazyčné mluvčí, Plzeň: Západočeská univerzita v Plzni. (Dissertation).

Společný evropský referenční rámec pro jazyky: jak se učime jazyküm, jak je vyučujeme a jak v jazycich hodnotime, 2002, Olomouc: Univerzita Palackého.

Š k o d o vá S., 2012, Kapitoly z lingvodidaktiky češtiny jako cizího jazyka, Liberec: Technická univerzita v Liberci. 